\title{
Exhumation processes in fourteen countries in Latin America
}

\author{
Susana Navarro García, Pau Pérez-Sales, and Alberto Fernández-Liria
}

\begin{abstract}
Exhumation processes are described in fourteen Latin American countries. They have been classified into four categories: 1) collective massacres (Guatemala, El Salvador, Colombia and Peru, 2) persons detained and disappeared as a result of state policies (Chile, Argentina, Uruguay, Brazil and Paraguay), 3) collective violence (Venezuela, Mexico and Panama) and 4) selective deaths under democratic regimes (Ecuador and Honduras). The events are described that made it necessary to start the exhumation process and other processes, analysing psychosocial accompaniment for relatives, whether it has been provided, and attempting to draw lessons from each experience on order to develop processes still outstanding in this and other continents.
\end{abstract}

\section{Introduction}

The euphemism 'forced disappearance' is used for a dramatic event that has occurred frequently in many countries of Latin America (Amnesty, 1994). Exhumation processes have been carried out in many of these countries in order to locate remains, determine what happened and to serve as a basis for justice and reparations (Pérez Sales \& Navarro García, 2007).

Systematic studies of these experiences have recently been published in Spanish and have resulted in collections of narratives (Pérez Sales \& Navarro García, 2007) by the organisations involved. Networks have also been developed for sharing experiences and for debate among these organisations, including significant milestones such as the first congress, held in Guatemala in 2007, and a second one held in Bogotá in 2010 (Ecap, Gac, \& Geza, 2007). 
These collective works have also served as the basis for the Working Document for an International Consensus on Minimum Standards for Psychosocial Work in Exhumation Processes (Ecap, Gac, \& Geza, 2009) (Table 1). These standards are necessary because, as we discussed elsewhere (Navarro-García, Pérez-Sales, \& Fernández-Liria, 2010), exhumation processes may be reparatory in nature but carry a risk of re-traumatizing the victims' families when not adhering to best practices.

In this work the exhumation processes developed during the last fifteen years in fourteen countries in Latin America have been reviewed. Each country has suffered different patterns of human rights violations considered in four categories:

1) Collective massacres. Massacre, as defined by the Commission for Historical Clarification of Guatemala, is understood as being the arbitrary execution of over five individuals in one place and as part of the same operation, when the victims were in a state of absolute or relative defenselessness. The concept of "one place" can refer to physical spaces of different types (house, canton, neighborhood, village or group of villages) as long as they are part of the same military operation. Massacres are usually associated with other serious human rights violations, such as torture, cruel treatment, enforced disappearance and sexual violations or aberrant conduct, such as the mutilation of cadavers and the destruction of property belonging to individuals, to the community or used for worship (Ecap, et al., 2009). [Guatemala (Navarro García, et al., 2007), El Salvador (Hernández, 2007), Colombia (Gómez López \& Martín Beristain, 2007) and Peru (Stornaiuolo, Chauca, \& Baca Soto, 2007)],

2) Persons detained and disappeared as a result of state policies [Chile (Baeza Fernández, et al., 2007), Argentina (Tumini, Garay, Bancheri, \& . 2007), Uruguay (Nadal, Pirotto, \& Robaina, 2007), Brazil (Bouças \& Vital, 2007) and Paraguay (Portillo, 2007)],

3) Collective violence understood as actions by the State or a National or foreign Army against popular movements or organizations or as a part of social cleansing policies, [Venezuela (Carrillo, 2007), México (Limas Hernández, 2007) and Panama (Sanjur, 2007)], and

4) Selective deaths under democratic regimes attributable to political reasons [Ecuador (Donoso, 2007) and Honduras (Oliva, 2007)]

According with the already cited International Consensus on Minimum Standards for Psychosocial Work in Exhumation Processes (Ecap, et al., 2009), by Psychosocial Accompaniment in Exhumation Processes, we understand "the process of providing accompaniment for individuals, relatives, the community or the society in order to cope with the consequences of the impact of serious human rights violations suffered by individuals, promoting well-being, and social and emotional support for victims and urging them to take action. The psychosocial dimension not only takes into account the individual, but also the family and the rebuilding of social support networks which have very often been destroyed as a consequence of violations." Psychosocial work is not the exclusive responsibility of specific teams of mental health professionals or community workers, but it is understood as being an element which should permeate every action taken by the different interdisciplinary team members who intervene in an exhumation (anthropologists, legal experts, lawyers, social workers, odontologists, ballistics experts, etc.).

A psychosocial perspective during an exhumation is understood as being the whole range of actions and processes which should be taken into consideration and/or developed in relation to an exhumation at the level of the individual, the family, the community and the society by all the institutions, teams and professionals who intervene in order to guarantee its 
reparative nature both for direct and indirect victims as well as for the society as a whole. (Ecap, et al., 2009)

In the majority of countries there has been no psychosocial accompaniment incorporated into the exhumation processes and in those cases where it has been provided there are no work protocols. In many cases accompaniment has been provided only at specific times.

\section{Exhumation experiences in 14 countries of Latin America}

\section{Exhumations in the context of genocide and collective massacres}

\subsection{Guatemala}

\section{The facts}

Most of the destruction caused as a result of political violence in Guatemala took place between 1980 and 1984. Massacres and forced disappearances were a product of the "razed earth" policy. The perpetrators of these massacres destroyed four hundred small villages.

The report Guatemala Never Again and the report of the Commission for Historical Clarification record that two hundred thousand people were killed in collective massacres and public murders, especially people of indigenous origin, over half of them being the victims of massacres. The state bears the main responsibility for these events ( $96 \%$ of all cases) (Navarro García, et al., 2007).

\section{Development of the process}

Guatemala is the country where exhumation processes have been most systematic, resulting in more reflection and representing a model for others. Between 1992 and 2006, about 700 exhumations were carried out with psychosocial accompaniment by several organisations. There are six institutions which provide psychosocial accompaniment for relatives ${ }^{1}$ and three forensic institutions.

The first exhumations were carried out during the armed conflict in 1988 in the villages of Chayamche and Pujujulito in the Department of Sololá. They were promoted entirely by civilians and performed by technical assistants from the departments, justices of the peace and forensic doctors. During the 1990s, and with support from the EAAF, the Guatemalan Forensic Anthropology Team was created, later becoming the Forensic Anthropology Foundation of Guatemala (FAFG). During this decade, changes occurred in the way people understood the problem of disappeared persons, and movements working for the peace process made it possible to focus exhumation processes on the search for truth and historical clarification.

Coordination between forensic anthropology teams and psychosocial teams was not easy and it took five years for them to sign the first agreement to work together. Current levels of coordination are the result of hard work in difficult situations.

\footnotetext{
${ }^{1}$ Community Study and Psychosocial Action Team - ECAP, Mutual Support Group - GAM, Maya Saq'be Centre, Utz Kaslemal, Bridges of Peace and ODHAG.
} 
The Commission for Historical Clarification, Truth and Justice in Guatemala, set up as a result of the Oslo accords of 1994, recommended an active policy of exhumations, representing a very important change in the social legitimacy of the process.

\section{Difficulties, lessons learnt and recommendations}

Exhumations in Guatemala have always been based on the demands of relatives. Unlike other countries, judges have never taken action as a matter of course without a request from either party on receiving notification of testimonies or evidence.

The first lesson to be learnt from exhumation processes in Guatemala is that psychosocial work is determined by the culture of the indigenous population which determines the meaning that people give to events. For the Mayan population exhumations permit the re-establishment of bonds with their ancestors and it is of central importance to work with dreams and premonitions. This is why it is essential for team members to be from the local culture (Navarro García, et al., 2007).

The second lesson is that exhumations should be understood as a long process of which excavation is only one part and, according to the teams, it is not necessarily the most painful part or the one during which psychosocial support is most necessary. The idea of excavation as a painful experience and psychological crisis requiring professional attention is not always confirmed by the experience of the teams. Emotional support during excavation has been requested by everyone except the relatives (Navarro García, et al., 2007).

Thus there is a need to work at all times with the relatives who should play an active part in the process and participate in all decisions. Psychosocial teams should take the time to become immersed in the community, ideally for several months, to be able to develop trust, explain their work, analyse the relatives' expectations, and discuss reparations policies and the possibility of justice. Furthermore, possible conflict scenarios should be considered with the community. It is essential to systematically include in this work critical reflection with the relatives about the advantages and disadvantages of initiating legal proceedings related to the massacres and the steps that need to be taken for this. It is important to keep in mind that $96 \%$ of the exhumations in Guatemala have not subsequently resulted in legal proceedings. Teams providing accompaniment, when reflecting on their own work, consider that they have not been sufficiently aware of this reality and have not systematically included in their work the provision of information or discussion of the possibility of legal proceedings.

Before the excavation it is of fundamental importance to work on understanding expectations of the results. The team should make every effort possible, using all available means to locate all the possible relatives of the deceased; otherwise they run the risk of causing more harm than good with the exhumation by enhancing unrealistic expectations that would result in frustration.

No less important is the devolution of the process and results to the families, which should be done systematically and using popular methodologies and collective activities. The violence was a collective event and the approach should also be collective. Part of psychosocial accompaniment consists of giving meaning to the experience of political violence, analysing with relatives and with the community the causes, the historical context and the current political context and lessons that can be learnt. An effort to define this methodology has been developed in the 
International Consensus (Ecap, et al., 2009). Considering its interest we include the list of recommended actions in Table 2.

For this inter-institutional support and coordination with organisations of victims working in the region are essential. In places where there are no organisations it should be a priority for the team to facilitate all possible conditions for the families to establish one.

Furthermore, beyond the local level and to reinforce the transformational effects of the process, it is important to promote municipal and departmental contacts to provide a broader perspective which may lead to an understanding of the overall context of violence and the way it affects the country as a whole, maintaining reports about the exhumations in the media.

\subsection{El Salvador}

\section{The facts}

Exhumation processes in El Salvador started in the framework established by the Truth Commission set up by the Peace Accords in Mexico City between the government and the FMLN in April 1991. The Truth Commission corroborated the gravity and dimension of crimes committed between 1980 and 1982, established as the bloodiest period in the history of the country. Similarly, perpetration of the crimes was not only attributed to local authorities, but civilians were also directly attacked as part of a state policy.

A paradigmatic case was the massacre of El Mozote, which occurred on 10 December 1981 , in the municipality of Meanguera in the Department of Morazán. It was perpetrated by the Atlacatl Infantry Battalion. The majority of people tortured and executed were women and children. In other departments, such as Chaletenango, similar events occurred as joint operations between military and paramilitary forces and in collaboration with the Honduran army (Hernández, 2007).

Many of the communities and survivors were further victimised after the massacres when obliged to live in refugee camps. It was only after 1990, when many people were repatriated, that the real conditions existed for initiating a search for testimonial information.

\section{Development of the process}

In view of the fact that there were several different versions of the events and because of the existence of rumours and misinformation during the years of political violence, exhumations, such as the exhumation at the site of the massacre of El Mozote, demonstrated the veracity of the events, pointing to those responsible for human rights violations. It was also possible to demonstrate the existence of an authentic policy of "killing the seed" as the logic behind the massacres.

From the beginning, the processes were led by organisations of relatives and nongovernmental human rights organisations. The church played a facilitating role and no psychosocial accompaniment was provided.

Two different stages can be identified in the process: first of all the exhumation itself and secondly the criminal prosecution of perpetrators. 
In view of the negligence of the Attorney General's Office, which failed to take action as a matter of course without the request of either party, the first stage was promoted by the relatives themselves, and they had to shoulder the burden of the search for justice. The judiciary limited itself to simply issuing permits for exhumations solely for humanitarian purposes.

Subsequent legal battles have continued for a very long time. After 17 years of national litigation, in 2006 the case of El Mozote was accepted by the Inter-American Commission for Human Rights in view of the absence of justice enforcement at the national level.

\section{Difficulties, lessons learnt and recommendations}

El Salvador exemplifies the difficulties which exist for working with state institutions when the state has been the perpetrator, especially in relation to forensic medical teams or forensic anthropology teams. The search for justice has been blocked when the military is implicated and because of the lack of independence of the judiciary.

Other difficulties have arisen as a result of the amnesty law, despite the fact that these are crimes against humanity and, as such, cannot be amnestied because they are related to inalienable rights. This element is present in many countries in Latin America and efforts are being made to repeal amnesty and full stop laws in other countries such as Argentina.

\subsection{Colombia}

\section{The facts}

In Colombia forced disappearances and massacres have been systematic events in the midst of a long lasting armed conflict. All participants in the Colombian conflict, with differing levels of responsibility, have used disappearance and massacres as a weapon of war.

Since 1977, records of victims of forced disappearance have been kept. There are at least 7,000 cases according to the Association of Relatives of Detained and Disappeared Persons (ASFADDES). During the 1970s and 1980s, most of the forced disappearances committed by the state or with the state's acquiescence were individual, with just a few cases of collective disappearances. Since the 1990s, there has been a massive increase in collective disappearances and massacres, both in the number of victims as well as the frequency. Since 2000, there has been an increase in the individual and systematic disappearance of persons from the same region, due to a violent process of land resettlement. On many occasions disappearances were linked to other violent events such as forced displacement which have affected over 3 million people (Gómez López \& Martín Beristain, 2007).

The emotional repercussions on families and communities are extensive and serious (Gómez López \& Martín Beristain, 2007). Constant uncertainty makes emotional closure impossible. Emotional pain is generalised among relatives and communities in addition to constant fear for those remaining in regions where these events occurred.

\section{Development of the process}

Exhumations have been made in a situation of active conflict, which presupposes an absence of guarantees for relatives, witnesses and teams, together with difficulty of access to regions where the relatives are located. 
In zones of paramilitary supremacy skeletal remains have been found and in guerrilla zones there are records of kidnappings of victims who subsequently died in captivity and have been buried in common graves. Because of the violence which exists in Colombia, this type of case can be found throughout the country.

Sometimes exhumations have been possible because a case has been won in the international tribunals as in the case of the massacre of 19 businessmen when authorities began the search process only when the Inter-American Court condemned the government of Colombia in 2004 (Gómez López \& Martín Beristain, 2007).

\section{Difficulties, lessons and recommendations}

On occasions the state has allegedly used exhumations as a way of breaking down the families, preventing them from participating in exhumations, making massive exhumations of clandestine graves and destroying the evidence or making no effort to identify remains and return them to the families (Gómez López \& Martín Beristain, 2007).

In the few cases in which families have managed to participate in exhumations carried out by the state, it has been because they have applied pressure, but the whole process of applying pressure to achieve participation is extremely exhausting for the families.

In the context of Law 975, recent exhumations, which are higher in number than ever before in the history of the country, have reproduced the problems that have been typical of searches for disappeared persons in the past and they are exceeding the capacity of state entities to respond to this problem (Gómez López \& Martín Beristain, 2007).

In Colombia there is no tradition of psychosocial accompaniment for exhumation processes, although it has existed in other contexts related to the conflict. Families have received support from communities and organisations of victims geographically close to them. However, a psychosocial response is required in Colombia for the situation of disappearance to help victims deal with the many difficulties (Gómez López \& Martín Beristain, 2007).

Exhumation processes are fraught with difficulties and require different solutions in order to adjust to the different typologies that can be considered for psychosocial accompaniment. Thus Gómez López and Martin Beristain (Gómez López \& Martín Beristain, 2007) distinguish between: a) Disappearances when the remains have been found or there is a possibility of finding them, b) Disappearances when the place of burial is unknown, and c) Disappearances when it will be difficult to recover the remains of victims.

Expectations must be adjusted to the circumstances in each of these typologies. And the strategies to facilitate grieving tasks should be adapted to them in the procedures and in the use of symbolic substitutes. 


\subsection{Peru}

\section{The facts}

Peru is one of the countries in which exhumation processes started during the internal armed conflict which lasted for almost 20 years. Terror and violence, both by the state as well as by the Shining Path guerrillas and the Tupac Amaru Revolutionary Movement (MRTA), created a situation in which massacres were frequently committed.

\section{Development of the process}

Exhumations are based on the logic of knowledge of the truth; exhumations have been one of the functions of the Truth and Reconciliation Commission (CVR). The dimensions of this work are enormous. Between February 2001 and August 2003, the CVR received about 17,000 testimonies and selected 1,923 interviews for the final report. The overall number of victims is about 70,000 people, $40 \%$ of whom were in the Department of Ayacucho. The CVR estimated that there were 4,644 burial sites and has made preliminary verification of another 2,200 probable burial sites. The public defence office has recorded about 8,304 disappeared persons, having ante mortem information about only 1,884 of these (Stornaiuolo, et al., 2007).

Serious mistakes were committed during the first exhumation processes, attributed to the inexperience of the teams and the absence of experts, and resulting in the destruction of evidence for legal proceedings. Many pieces of evidence were destroyed and the identification processes became really difficult.

In Peru, exhumations can only be made by institutions linked to the public prosecution office. Non-governmental organisations, unless they are specifically asked to provide a specialist report by the public prosecution office or by the courts, have no direct participation.

In many cases the work of the Legal Medicine Institute (IML) is limited to the excavation phase and the identification of bodies and subsequent burial is left pending. The participation of families in the process is usually limited or non-existent, and in some cases they have not even been aware of the exhumations.

The IML forensic team does not provide any psychosocial accompaniment, nor does it coordinate with other institutions that do so. Psychosocial accompaniment, when provided, has been by social organisations and essentially during the excavation phase with very little prior work done. In nearly all the exhumations work has been done with school teachers but this, with few exceptions, has been very specific and in the departments there is no mental health network capable of providing follow-up to serious cases of emotional disorders. Organisations which work in the legal or judicial field have not always been aware of the need for psychosocial support. Coordination between state entities, families, victims' organisations and human rights organisations is very deficient.

Many communities fail to accompany the victims and their families, leaving them alone or demanding that families subject their decisions to community requirements. This clearly shows that there is a need to incorporate community work so that communities support victims. 
Although, as in Guatemala, exhumation may be contemplated by the communities as a form of re-establishing their bond with the deceased, there are some families that do not want their relatives to be exhumed, either because they refuse to accept their loss, or because they perceive it as a useless expense in the context of extreme poverty.

The political exploitation of exhumations has been one of the obstacles to their practice.

\section{Difficulties, lessons learnt and recommendations}

The laws should be changed to prevent the viability of legal proceedings depending on who is governing the country.

Cooperation agreements should be established between entities that provide psychosocial accompaniment and the IML.

The IML should publicise its exhumation calendar in advance in order to plan its work, establish prior relationships with the families and members of the communities and locate survivors.

In places where the armed conflict led to confrontations between groups in the community, a process of retrieving the values and common history should be embarked upon. The reconciliation process should be seen in the long term and it should not be forced or limited to the exhumation.

\section{Persons detained and disappeared as a result of state policies}

\subsection{Chile}

\section{Development of the process}

In Chile the first exhumations were made during the dictatorship. The huge social impact of the remains found at the Ovens of Lonquén led Pinochet's government to try to remove them from the illegal burial sites, which represented a double disappearance, an event similar to what is currently happening in Colombia.

In general, exhumation processes have had a huge social impact (in addition to the Ovens of Lonquén, especially at the concentration camp of Pisagua and Patio 29 in the cemetery of Santiago) and direct repercussions on the social interpretation of violence and, after the dictatorship, on the evaluation of governmental performance in the field of human rights (Baeza Fernández, et al., 2007).

Exhumations form part of the Chilean state's policy of reparations. For the Chilean state, identification is the most important element, in contrast to Colombia where the state makes no effort to identify remains. However, a lack of political will for doing serious and effective work in relation to disappeared persons has been pointed to. Progress has been achieved because of pressure by the families, lawyers and human rights organisations (Baeza Fernández, et al., 2007).

Currently, the most common way to carry out exhumations is based on information obtained during an investigation of a disappeared person when the judge takes legal action as a matter of course without a request from either party, or pressure is applied by the associations of relatives. The Legal Medicine Service (SML) is the only body authorised to perform exhumations, and it is usually civil society 
anthropologists who serve as experts for the party to the action (as in Peru). The families are informed by the team providing accompaniment or by the association.

Support for relatives has been provided by human rights organisations and particularly by the associations of relatives of victims.

The state provides emotional accompaniment as part of its responsibilities and has its own team to do this work (unlike other countries, such as Peru, where this is not provided, or where the state funds independent bodies trusted by the families, such as in Guatemala). Psychological support provided by the state is started before the excavation (preparation work) and continues at different times afterwards. The psychosocial team is considered responsible for providing information about progress in the anthropological study, which has been questioned in some other places where it is thought that it should be the judges (such as in Argentina) or the anthropologists themselves (such as in Guatemala). When families live in urban areas, the work is not done collectively. Exhumations are understood to be spaces for confirming a death previously suspected but denied and as the end of a search process and a series of stages (unlike Argentina, for example). The need to include children and grandchildren in ceremonies and symbolic processes has been indicated, and continuous accompaniment is required. In Chile, experience has shown how new information about clandestine graves has a complex effect on the families. Furthermore, the fact that as a consequence of the "double disappearance", only small bone fragments have been found in the majority of cases, makes it difficult for the relatives to symbolise their loss.

\section{Difficulties, lessons learnt and recommendations}

The identification process may last up to 5 years, which often leads to a breakdown of the process for the families. Mistaken identifications have been made, some of which have been very significant, such as the case of Patio 29 where years after making identifications using classical methods, relatives who already had their doubts, asked for DNA confirmation. These situations can have a very negative effect on the families. The military have used these false identifications - introducing rumours as reliable information - as a way of breaking down the families during their search. This has also occurred in Argentina and Colombia.

Associations of relatives have become exhausted after years of pain, frustration and failure to resolve cases. The nature of the legal proceedings themselves has sometimes represented a re-traumatisation for the families, and accompaniment provided by the state as well as by human rights institutions has been insufficient.

This exhaustion and the fact that the majority of disappearances occurred over 20 years ago has meant that the issue is not a priority for the associations of relatives. This feeling of distance is even greater among people of Mapuche origin who sometimes appear to have very ambivalent attitudes (Baeza Fernández, et al., 2007). There is a long list of reasons why, with the passage of years, relatives may often prefer not to carry out an exhumation: fear of not finding anything, fear of losing a version of events that they have already accepted and find reassuring, fear of bringing up matters they considered they had already resolved, social pressure to forget or become "reconciled" or find alternative spaces of symbolisation and communication with the deceased which do not require the loved one to be in a specific physical place. 
This does not mean that for some families it is not very important to find the remains of their loved ones, but for others this importance seems to be diminishing (Baeza Fernández, et al., 2007).

An evaluation is to be made of the consequences of the fact that it is the state itself that provides accompaniment, since this has been experienced as negative by some families and as reparatory by others. For the Mapuche people, the funerals of the few people located have become political acts and have no reparatory value in their culture. Experiences of unsuccessful excavations and the fact of not having taken into account the motivations of the families (search and justice) seem to have led to a certain disillusionment among families and human rights organisations, resulting in limited participation (Baeza Fernández, et al., 2007). People may have different agendas to the human rights organisations. From the logic of a relative, in pragmatic terms an exhumation makes sense if legal processes almost permanently postponed can be unfrozen.

A discussion has arisen about the advantages and disadvantages of the existence of DNA laboratories and national registries of disappeared persons in relation to the political context and the role of the state as perpetrator. With regard to DNA evidence, there has been reticence in the sense that identifications have increased but proceedings have become individualised. The search and exhumation processes are no longer part of a collective process belonging to the community, but a private space for an individual or family. The use of DNA has been described as an advantage which avoids re-traumatisation of repeated processes of recognition and greater reliability for recognition when possible.

In any case, in the light of experience, it seems clear 1) that in all actions for reparation of damages the participation of families and human rights organisations should be required, 2) that measures should be taken that are conducive to the development of judicial proceedings and 3) that it would be convenient to annul the Amnesty Law that has served to conceal impunity in Chile (Baeza Fernández, et al., 2007).

\subsection{Argentina}

\section{Development of the process}

Exhumations with scientific techniques were started when the political context permitted it in 1984 with the arrival of the American Association for the Advancement of Sciences; Argentina was the first country in Latin America that started to perform exhumations as part of the process of searching for disappeared persons, at the request of the National Commission on the Disappeared and the Grandmothers of the Plaza de Mayo. During that visit, the Argentine Forensic Anthropology Team was created (Tumini, et al., 2007).

The emphasis in the current process in Argentina is on the relation between forensic anthropology as a technical discipline and psychosocial accompaniment, with examples of these experiences in Buenos Aires, Córdoba, Jujuy and the town of Rosario.

Right from the start, the organisations of relatives have played an important role in the search processes. Exhumations have formed part of a broader strategy in the struggle of organisations of relatives of disappeared persons. 
The human rights field is conflictive. As happens in the category of "disappearances", in Argentina there has not always been consensus with regard to exhumations. There is no doubt that exhumations, in themselves, cannot provide reparations for all the events experienced: vacuums, impunity and misinformation. There are some organisations of relatives that reject these using political and ideological arguments.

This has led to debate between people with different agendas in relation to exhumations. When interests and the visions of human rights groups fail to coincide with those of the families, do the remains of the deceased belong to the families or to the society as a whole? If an exhumation may serve to document human rights violations and legal proceedings against perpetrators, but the family does not wish to carry out the exhumation, which opinion should prevail?

As in other countries, such as Venezuela, the overriding motive is the search for justice and truth and not merely emotional elements, although these elements are present among organisations of relatives. In the specific case of HIJOS the approach is based on a political struggle, and when exhumations have been performed, the human and emotional nature of these processes has been revealed.

In Argentina a great deal of psychological support has been provided for relatives of disappeared persons and survivors of torture, and a large amount of theoretical work has been done, but exhumation processes have not been identified as fields where this work is relevant.

Each case is different in Argentina, although the presence of relatives during this phase depends on the laws in the region where the exhumation is being carried out. Also present is the concern by the forensic anthropology team that relatives will have expectations of positive results from the exhumations, but imponderable factors related to the work will often result in these not being achieved (Tumini et al., 2007).

After the excavation phase, the families should participate actively and they should be the ones to decide how the remains are to be returned. There are some justice institutions that become involved in the processes, in some cases resulting in symbolic acts of recognition (the reading of records).

Relatives are sceptical about the application of justice in relation to disappeared persons, believing that it is difficult to trust the judicial system, even when appealing for its implementation.

There is a need for opportunities for discussion for the teams (anthropology teams, workers ....) (Tumini et al., 2007).

Difficulties, lessons learnt and recommendations

In addition to the above, the Argentine experience has demonstrated the need to incorporate psychosocial work at all times during the exhumation processes, as well as strengthening the participation of the society in general in the ritual of handing over the remains to the relatives since this would represent social recognition of the events (Tumini, et al., 2007). 


\subsection{Uruguay}

\section{The facts}

The repression of leftist movements in Uruguay started at the end of the 1960s even though the state was formally democratic. State terror in Uruguay after the coup d'état in 1973 was very similar to the other countries of Latin America, such as Argentina. The use of prolonged pressure and torture was systematic; 10,000 people were imprisoned out of a population of 2.789 .000 between 1972 and 1984 . The Association of the Mothers and Families of the Detained-Disappeared of Uruguay has identified 200 disappeared persons (Nadal, et al., 2007).

\section{Development of the process}

Few exhumations have been carried out, but they have had a huge social impact, the first one being described as an authentic collective process involving the Uruguayan people. This has been the experience in the majority of countries in which the first exhumations unite many sectors of the population.

Exhumations are made under an agreement between the government and groups of archaeologists. Due to the absence of experience and background in exhumation processes, there has been a lack of coordination. The possible location of disappeared persons in different countries, such as Argentina and Chile, has made it difficult to find them. Because of the Law on Impunity it was impossible to seek legal action for a long time. It was not until 2006 that some cases were taken to the Uruguayan and Chilean courts.

Exhumation processes have resulted in ethical positions being adopted by archaeologists in their relation to the families of disappeared persons. The archaeologists in certain countries consider that their witness must be based on their findings and therefore, if they work too closely to the relatives, their declaration might be considered partial and invalid. They prefer not to let relatives participate, not to share mobilization or food with them and so on. The point is to avoid being rejected as a witness by the other party's lawyer. In such cases, the families scarcely participate in the excavation process. The processes are started after information is received by the commission and investigations are begun.

So far the relatives' organisation has no defined policy for exhumation processes; these have simply provided effective emotional support for families.

There has been no psychosocial accompaniment for exhumation processes. Organizations that have provided psychological support for families of disappeared persons have done so after feeling moved by the exhumations.

Similarly to other countries, justice is more important than economic reparations. Exhumations are seen as a small part of a much larger process (Nadal, et al., 2007).

\section{Difficulties, lessons learnt and recommendations}

There has been debate about public and private roles in exhumation processes and the search for disappeared persons: exhumation represents a public space, which obliges families and the teams to adopt a public role for which they are not necessarily prepared or do not necessarily want. How can this be combined with the private sphere? 
Years of therapeutic work have shown that commitment, or non neutrality, is the basic central element for working with the families of disappeared persons, as well as the incorporation of social dimensions in therapeutic work. These lessons were a result of the interrelation between the needs of relatives and the form and position of psychological work.

From the lessons learnt in this experience some possible recommendations can be made, such as 1) The need to separate the work of the search and exhumation processes from the presidency of the republic, creating an independent governmental body, 2) The creation of an interdisciplinary psychosocial work group in the framework of a truth commission, 3) Annulment of the State Punitive Claim Expiration Law (Law on Impunity), 4) Development of an Integral National Reparations Programme (Nadal, et al., 2007).

\subsection{Brazil}

\section{The facts}

Over forty years after the establishment of the military regime in Brazil, Brazilian society has still not definitively clarified the violations which occurred during the period of state terrorism. It was only after the deaths of some internationally known opponents in 1975 that the state considered it necessary to attribute their deaths to accidental causes or to the resistance. Up to that point, forced disappearances had been the norm. In Brazil there has been a generalised practice of common graves in which unidentified people are buried. This is significant for the destitute as a mechanism of social cleansing. In Brazil social cleansing is systematic and continues to occur at the hands of death squads that use these common graves, with no attempt by the authorities to locate relatives or to find the perpetrators.

\section{Development of the process}

In Brazil there has been no support from the judicial authorities for exhumation and search processes. Relatives, organisations and private individuals have implemented/financed forensic processes voluntarily, despite the fact that in Rio de Janeiro over 2,000 remains have been found, which has represented a huge volume of work. It has been the persistence of the families that has allowed these processes to advance.

There has been no accompaniment for families during this process, only individual support in some cases.

Exhumations have only resulted in the identification of eight persons, but the social impact and the impact in the media of these exhumations has been huge with media presence and high impact images which have led to the start of a debate on violence during the dictatorship (as in Venezuela, Ecuador and Mexico).

Hospitals contain the remains of hundreds of unidentified persons, mainly of destitute people, but also some political prisoners (as in Venezuela).

After the exhumations were made, two forensic doctors were barred from practising their profession because of having issued forged death certificates. This was the first case of its kind in Latin America. 
The state has not taken judicial action as a matter of course, nor has it supported the relatives, who have had to shoulder the responsibility of seeking evidence and initiating proceedings.

Despite successive changes of government and the existence of leftist governments, the terror archives, known to exist, have still not been opened.

\subsection{Paraguay}

\section{The facts}

The practice of forced disappearance was systematic in Paraguay, particularly between 1959 and 1962 after the coup d'état by General Stroessner. It continued after these dates but in a more selective manner (Portillo, 2007).

\section{Development of the process}

The processes have been implemented in the context of the Truth and Justice Commission. Accompaniment has been provided that has not been limited to the excavation but has been continued, starting with the initial work of searching for information up to legal proceedings or the presentation of demands by relatives to the parliament.

\section{Difficulties, lessons learnt and recommendations}

It is thought that years will be spent on the search as the work of the Truth Commission progresses. Organisers of the processes are demanding the creation of a National Genetic Data Bank to facilitate identification. They are also demanding the adaptation of Paraguayan legislation to international requirements and the creation of a permanent mixed human rights secretariat with the participation of the state and civil society in order to extend the frame of action of the Truth and Justice Commission.

\section{Exhumations in the context of social violence}

\subsection{Venezuela}

\section{The facts}

The presidential decree of 28 February 1989, which suspended constitutional guarantees to facilitate the repression of protests as a result of economic measures taken by the government, led to a period of almost one month of actions by the army and the police, resulting in numbers of dead and wounded that have still not been quantified, especially in the city's poor neighbourhoods. Official estimates were 276 dead, but when the grave of La Peste was found with 68 unidentified bodies that were not on the official list, this estimate was discredited. In 1999, 437 lawsuits were filed in the courts for death or injury (Carrillo, 2007).

\section{Development of the process}

A long legal battle was required for the exhumations and it took 18 months to issue the order to open the common grave. After 17 years of criminal proceedings and a favourable sentence by the Inter-American Court of Human Rights, investigations are still in the preliminary phase and no case has been heard in the national courts so far. A large number of bodies are still unidentified (as in El Salvador). 
The families promoted and implemented most of the process (locating other families, making ante mortem records, clearing the area, participating in the excavation, and protecting and watching over the remains).

In Venezuela the search for justice has been the main driving force for the families, rather than grief or emotional issues (unlike Guatemala or Peru but similar to Argentina or Brazil).

Since the exhumation, the Committee of the Relatives of the Victims of the Events that Occurred in February and March 1989 (COFAVIC) was set up as a human rights organisation which works on all kinds of issues in the country as well as providing training for the armed forces and the police, human rights education and other activities (like Honduras and Panama).

Many relatives have said that the group was like "their new family". A significant group of people (5-15 at certain times) worked full-time to achieve exhumations.

The relatives managed to establish a broad national solidarity movement (schools, universities, the church, trade unions).

The state tried to avoid exhumations by appealing to "sanitation" reasons (as in Panama) not supported by international reports. Successive governments were responsible for obstructing efforts and relatives were threatened by state officials.

After the exhumation, the Legal Medicine Institute manipulated the remains, destroying expert evidence and burying the remains a few hours later. The relatives were only given identical certificates confirming death by firearm, with no further information nor burial activities (as in Panama and Columbia) (Carrillo, 2007).

\section{Difficulties, lessons learnt and recommendations}

The main difficulties stem from the fact that the state is both judge and party. Those responsible for investigating events may be interested in perpetuating impunity. The relatives need to have reliable entities participating in the proceedings.

Some lessons learnt from the Venezuelan process are the importance of social activism and mutual support for the mourning process, even without the existence of a psychosocial team, and the importance of symbolic elements such as marches, meals, liturgical celebrations and other encounters (Carrillo, 2007).

\subsection{Mexico}

\section{The facts}

In Ciudad Juárez, a town on the border with the United States, over 400 women have been murdered in the last 14 years. Most of these murders have still not been clarified. 100 of them are sexual crimes with indications of serial murder. They are attributed to organised crime and mafia groups. They have frequently been accompanied by the condemnation, attribution of guilt and stigmatisation of their families (Limas Hernández, 2007).

\section{Development of the process}

It is the families that have sought clarification of events. Proceedings brought by state entities have, as a whole, been an accumulation of judicial and expert 
negligence. The proceedings have sometimes been re-traumatising for different reasons. First because of the false identifications that may have been made because of the tendency to accept insufficiently proven identifications (as occurred in Patio 29 in Chile) and, furthermore, because of the conditions in which the exhumations were performed as well as the handing over of remains to relatives in the absence of adequate psychosocial accompaniment, especially with the frequent occurrence of factors such as facial disfigurement or signs of torture.

This mistreatment of the families by state entities and the absence of accompaniment have led to the creation of a "victim's identity" among some relatives, which could be considered as a double victimisation.

The response of solidarity and support, for example through artistic expression, has been of central importance (Limas Hernández, 2007).

\section{Difficulties, lessons learnt and recommendations}

Analysis of the processes in Ciudad Juárez has revealed the need for psychosocial accompaniment capable of preventing the possible harmful effects of exhumation processes. This is why it is essential to incorporate it into all forensic anthropology and judicial actions, establishing cooperation agreements with organisations that provide accompaniment and that enjoy the trust of the families.

Given that legal proceedings are necessary for the possibility of reparations, it is essential that psychosocial accompaniment specifically tackle this aspect as a priority, for example through education in human rights or on the legal process.

The need has also been identified to incorporate the gender perspective into exhumations related to crimes against women and adding a psychosocial perspective beyond the vision of posttraumatic stress disorder.

Of course it will also be necessary to coordinate all scientific resources available to guarantee the correct identification of victims (Limas Hernández, 2007).

\subsection{Panama}

\section{The facts}

Cases of forced disappearances in Panama date back to the period of the dictatorship after the coup d'état by Omar Torrijos in 1968 which lasted until 1981, and the American invasion which occurred in December of that same year (Sanjur, 2007).

\section{Development of the process}

As in other countries, the relatives have played an important role in the whole process, presenting many of the petitions to the state. After the exhumation processes, the families organised themselves with support from social institutions. The establishment of the Truth Commission has been one of the many achievements of this struggle by the families.

There has been no psychosocial accompaniment, although the relatives have been receiving a great deal of support from human rights organisations since the beginning of exhumations resulting from events during the dictatorship. 
The methods used to search for disappeared persons by the state of Panama have been systematically inadequate, which has delayed the different processes (Sanjur, 2007).

\section{Difficulties, lessons learnt and recommendations}

The first lesson that has emerged from the process in Panama is that exhumations should not be the responsibility of the states; they require direction by independent bodies. A second lesson would be the need to attend and guarantee witness protection (Sanjur, 2007).

\section{Exhumations in the context of selective deaths under democratic regimes}

\subsection{Ecuador}

\section{The facts}

In Ecuador disappearances have occurred under democratic governments. For instance, in an open communication to Judge Baltasar Garzón, the government of Febes Cordero has been held responsible by the civil society and the main human rights organisations in the country "for at least 124 murders, 215 cases of torture and inhuman and degrading procedures, 94 violations of homes, over 435 arbitrary arrests, over 113 cases of solitary confinement and dozens of cases of disappearances. None of these crimes has been punished" (Donoso, 2007).

\section{Development of the process}

Also in Ecuador, it has been the tenacity of the families in their search for their disappeared relatives that has promoted the process. State entities have intentionally misinformed and manipulated the families in order to obstruct search processes.

There have been no psychosocial accompaniment teams, either for exhumations or for human rights in general. The accompaniment that has been provided has only been through mutual support provided by human rights organisations or volunteers.

Impunity persists and events related to disappearances have not been clarified either at the national level or at the international level. Despite convictions against the Ecuadorian state, it has not complied with judicial investigation in any of the cases.

When indemnification has been awarded, it has, on occasions, led to family conflict, partly because of the absence of interventions to contribute to an understanding of the meaning of reparations (Donoso, 2007).

\section{Difficulties, lessons learnt and recommendations}

There is an urgent need for a centre to provide psychosocial attention for victims of human rights violations and to attend needs detected during the process (Donoso, 2007).

\subsection{Honduras}

\section{The facts}

In Honduras, forced disappearances were committed under the constitutionalist governments in the 1980s and at the beginning of the 1990s. Paradoxically, this has 
prevented access to classified information. Those responsible have at all times maintained a share of political power which has been sufficient to guarantee their impunity (Oliva, 2007).

\section{Development of the process}

Since the news was first published of the existence of unidentified bodies in different geographical areas of Honduras in 1980, the families have struggled to achieve identification. In 1982, the Committee of Relatives of the Detained - Disappeared in Honduras (COFADEH) was created and was able to locate different clandestine graves. During the same year, six bodies were discovered - still unidentified - in "La Montañita" outside Tegucigalpa. The National Reconciliation Commission was set up in 1987. The first exhumations, however, were not made until 1994. Two state institutions were involved, the Attorney General's Office and the National Human Rights Commission, in addition to non-governmental human rights organisations from Honduras with support from the Argentine Forensic Anthropology Team. Of the 16 bodies found, five have been identified (Oliva, 2007).

\section{Difficulties, lessons learnt and recommendations}

Scientific exhumation processes are a necessity, not only because of the expectations of the families of recovering the remains of their loved ones, but also because they contribute to strengthening the right to the truth as the inalienable right of relatives of victims as well as of the society in general that experienced these events and the grave and systematic violations of human rights.

The development of an information campaign is urgently needed at the national and regional levels on procedures to follow when human remains are found and the importance of these findings as evidence for criminal investigation.

COFADEH considers that exhumation processes practiced so far have failed to achieve a positive impact in relation to obtaining justice and the restitution of remains to their relatives, but a collective awareness of the past has been developed and to a certain extent this has contributed to revealing the truth about events.

With regard to the adoption of national mechanisms to clarify events, it is necessary to create a data base to store information related to the remains found in clandestine graves so that this information can be used at any time, and also, considering that the maternal ancestors of victims are now elderly, to create a genetic information bank.

The application of justice in relation to exhumations is a central variable for reconciling the past, but postponing identification for unreasonable periods of time will only serve to make the process more painful (Oliva, 2007).

\section{Conclusions}

This review of exhumation processes in 14 countries in Latin America (with results summarized in table 3 allows us to draw the following conclusions.

1. Unlike other continents, exhumation processes in Latin America have been promoted by relatives of the disappeared who have become involved in the process of the search for truth, justice and reparations.

2. The participation of the governments and of the justice systems has been extremely varied and there is some debate about what the best role should be for these when the 
state is implicated - or when there are suspicions of state implication - in the events being investigated.

3. On occasions there has also been conflict - which sometimes affects schedules, but also more substantial aspects - motivated by objectives which do not always coincide between processes implemented by the families and those implemented by human rights organisations.

4. Psychosocial accompaniment has not always existed, but when it has, it has not always been adapted to the needs of the people.

5. For psychosocial accompaniment to be useful, it needs to be seen as a long process which starts before and continues after the exhumation, taking measures to guarantee the inclusion of cultural and gender perspectives and tackling the collective dimension of the process.

The analysis of similarities and differences between these processes allow us to learn useful lessons to avoid past mistakes. If the main aim of the exhumation process is to make possible a rebuilding of the social fabric after violent events, key issues that must be carefully considered are ways to encourage and strengthen the involvement of victims, communities and society as a whole in the process, the role of cultural peculiarities in each community, the relationship between technical support and community organization, the role of Justice and the State and the political context. This has been done when building the International Consensus on Minimum Standards for Psychosocial Work in Exhumation Processes (Ecap, et al., 2009). A detailed description of this process of learning (Beyond the scope of the present work) has been published elsewhere by the authors (Navarro-García, et al., 2010).

Contact information/Correspondence:

Susana Navarro García

2da. Avenida 1-11, Zona 3. Colonia Bran, Guatemala, C.A

Email: susananava@gmail.com

Susana Navarro García, Psychologist. Coordinator of Psychosocial Work in Exhumation Processes. Community Study and Psychosocial Action Team (ECAP) Guatemala (Guatemala); Pau Pérez-Sales, Psychiatrist. Community Action Group. La Paz University Hospital. Madrid (Spain); and Alberto Fernández-Liria, Psychiatrist. Community Action Group. Príncipe de Asturias University Hospital. Madrid (Spain)

This work has been possible with the financial support of the Catalonia Agency for cooperation and development (Agència Catalana de Cooperació al Desenvolupament) and the Austrian Development Agency - ADA 


\section{References}

Amnesty, I. (1994). Disappearance and political human rights crisis of the 1990's: a manual for action. Amsterdam: Amnesty International.

Baeza Fernández, V., Madariaga, C., Brinkmann, B., Bacic, R., Pérez Sales, P., \& Durán, T. (2007). Yuxtaposicion de las miradas. Los dilemas de la identificación y la importancia relativa de los restos. In P. Pérez Sales \& S. Navarro García (Eds.), Resistencias contra el olvido: Trabajo psicosocial en procesos de exhumaciones (pp. 115-151). Barcelona: Gedisa.

Bouças, C. M., \& Vital, V. (2007). Exhumar e identificar muertos y desaparecidos politicos: una contribución del Grupo Tortura Nunca Mais (GTNM/RJ) para el rescate de la memoria. In P. Pérez Sales \& S. Navarro García (Eds.), Resistencias contra el olvido: Trabajo psicosocial enj procesos de exhumaciones (pp. 213-234). Barcelona: Gedisa.

Carrillo, C. (2007). El Caracazo: exhumación y lucha por la búsquyeda de la justicia. In P. Pérez Sales \& S. Navarro García (Eds.), Resistencias contra el olvido: Trabajo psicosocial en procesos de exhumaciones (pp. 247-266). Barcelona: Gedisa.

Donoso, G. (2007). Justicia y atención psicocial: desafíos para la memoria y la reparación integral. In P. Pérez Sales \& S. Navarro García (Eds.), Resistencias contra el olvido: Trabajo psicosocial en procesos de exhumaciones (pp. 299-312). Barcelona: Gedisa.

Ecap, Gac, \& Geza. (2007). Memorias del I Congreso Mundial Trabajo psicosocial en procesos de exhumaciones, Desaparición Forzada, Justicia y Verdad. Guatemala: ECAP.

Ecap, Gac, \& Geza. (2009). Working Paper on International Consensus on Minimum Standards for Psychosocial Work in Exhumation Processes for the Search of the Disappeared Persons. Guatemala: F\&G Editores.

Gómez López, A. M., \& Martín Beristain, C. (2007). Retos para el acompañamiento psicosocial de familiares de personas desaparecidas en el contexto de exhumaciones. In P. Pérez Sales \& S. Navarro García (Eds.), Resistencias contra el olvido: trabajo psicosocial en procesos de exhumaciones (pp. 45-60). Barcelona: Gedisa.

Hernández, M. J. (2007). Masacre de El Mozote y sitios aledaños: La búsqueda de espacios para la lucha legal. In P. Pérez Sales \& S. Navarro García (Eds.), Resistencias contra el olvido: Trabajo psicosocial en procesos de exhumaciones (pp. 37-44). Barcelona: Gedisa.

Limas Hernández, A. (2007). Derechos humanos e intervención psicosocial: del feminicidio y las exhumaciones de víctimas en Juárez. In P. Pérez Sales \& S. Navarro García (Eds.), Resistencias contra el olvido: Trabajo psicosocial enj procesos de exhumaciones (pp. 267-283). Barcelona: Gedisa.

Nadal, O., Pirotto, E., \& Robaina, M. C. (2007). Acompañamiento psicosocial en procesos de exhumación de detenidos-desaparecidos. In P. Pérez Sales \& S. Navarro García (Eds.), Resistencias contra el olvido: Trabajo psicosocial en procesos de exhumaciones (pp. 187-212). Barcelona: Gedisa. 
Navarro-García, S., Pérez-Sales, P., \& Fernández-Liria, A. (2010). Exhumations in Latin America: Current Status and Pending Challenges: A Psychosocial View. . Volume, Issue .. Peace \& Conflict Review, 4(2). Retrieved from http://www.review.upeace.org/pdf.cfm?articulo=100\&ejemplar $=19$

Navarro García, S., Kernjak, F., Chalín, Y., Pedraza, E., Conos, S., García Lanceiro, A. L., et al. (2007). Veinte años de exhumaciones: un largo proceso de aprendizaje. In P. Pérez Sales \& S. Navarro García (Eds.), Resistencias contra el olvido: Trabajo psicosocial en procesos de exhumaciones (pp. 61-91). Barcelona: Gedisa.

Oliva, B. (2007). El valor de la verdad y de los procesos de búsqueda de desaparecidos. In P. Pérez Sales \& S. Navarro García (Eds.), Resistencias contra el olvido: Trabajo psicosocial en procesos de exhumaciones (pp. 313-326). Barcelona: Gedisa.

Pérez Sales, P., \& Navarro García, S. (2007). Resistencias contra el olvido: trabajo psicosocial en procesos de exhumaciones. Barcelona: Gedisa.

Portillo, C. (2007). Primeros pasos desandando el pasado. In P. Pérez Sales \& S. Navarro García (Eds.), Resistencias contra el olvido: Trabajo psicosocial en procesos de exhumaciones (pp. 235-243). Barcelona: Gedisa.

Sanjur, C. (2007). Desaparecidos: investigaciones y excavaciones. In P. Pérez Sales \& S. Navarro García (Eds.), Resistencias contra el olvido: Trabajo psicosocial en procesos de exhumaciones (pp. 285-295). Barcelona: Gedisa.

Stornaiuolo, M., Chauca, R. L., \& Baca Soto, N. (2007). Acompaxamiento psicosocial en procesos de invesstigación antropológica forense en Perú. In P. Pérez Sales \& S. Navarro García (Eds.), Resistencias contra el olvido: Trabajo psicosocial en procesos de exhumaciones (pp. 93-112). Barcelona: Gedisa.

Tumini, M. C., Garay, L. S., Bancheri, C. M., \& . (2007). Procesos de exhumaciones: un espacio posible. In P. Pérez Sales \& S. Navarro Garcia (Eds.), Resistencias contra el olvido: Trabajo psicosocial en procesos de exhumaciones (pp. 153-185). Barcelona: Gedisa. 


\section{Table 1: International Consensus on Minimum Standards for Psychosocial Work in Exhumation}

\section{Search for persons who have been the victims of enforced disappearance, extrajudicial and arbitrary executions}

Standard 1: All efforts must be made to search for victims of enforced disappearance and extrajudicial and arbitrary executions until they are found, clarifying the events regardless of when they occurred or requiring prior formal denunciation on the part of the relatives themselves, avoiding by all possible means any obstacles for the search processes.

\section{Finding the relatives}

Standard 2: All conceivable efforts must be made to identify, find and facilitate the participation of the possible relatives of victims of enforced disappearance and arbitrary and extrajudicial executions, before starting forensic investigations and legal proceedings.

\section{Active participation of relatives}

Standard 3: Efforts must be made to promote and facilitate the active participation of relatives in the processes to search for the victims of enforced disappearance, extrajudicial and arbitrary executions and in the forensic investigations, favoring the existence of spaces where individuals can organize and reaffirm themselves, as well as take well- informed decisions in view of the technical and legal processes that affect their rights to justice, memory and comprehensive reparation.

\section{Clarifying the events, right to truth and memory}

Standard 4: The investigation of cases of enforced disappearance, extrajudicial and arbitrary executions and other human rights violations should be promoted until the events are fully clarified. Likewise, the conditions for the victims to reconstruct their historical memory should be facilitated as part of the process to ensure dignity and non-repetition.

\section{Right to justice}

Standard 5: The State must adopt both national and international measures of a legislative, administrative, judicial or any other nature, to ensure the full observance of the individual and collective rights to justice at individual, family, community and social level.

\section{Comprehensive reparation}

Standard 6: The rights of victims of enforced disappearance and other human rights violations to comprehensive reparation, contemplated in national and international regulations, must be acknowledged and put into practice and the necessary actions must be implemented in order to fulfill such rights and demands by victims, relatives and communities. The psychosocial perspective must be considered within the individual and collective processes, and the historical experiences, expectations and differential needs for reparation of individuals, families and communities should be actively integrated.

\section{Protection and Security}

Standard 7: To make available all necessary means for relatives to search for their loved ones and endeavor to clarify the events in conditions of dignity and security, in contexts of armed conflict or ongoing human rights violations. This security shall also be extended to all information obtained throughout the process, from evidences and proves to testimonies and reserved, personal information. 


\section{Constant information and transparency of the processes}

Standard 8: During the process of searching for missing or arbitrarily executed persons, the relatives should be constantly informed, in a clear and precise manner, favoring clear decision making about future actions. The right to information includes: (a) access to know about the process of searching for missing or executed persons, the forensic investigation, its actions, implications, consequences and rights; this is particularly relevant on aspects of comprehensive reparation and the right to justice. (b) progress made, limitations and technical and legal relevant elements. (c) access to know the findings to elucidate responsibilities, the conduct of the perpetrators towards the victims, and what were the motives to commit the crimes.

\section{Right to psychosocial care}

Standard 9: Psychosocial care should be a fundamental pillar of the duty to provide humanitarian assistance to communities and relatives of victims of enforced disappearances, arbitrary or extrajudicial executions and serious human rights violations. All the necessary steps should be taken in search processes to prevent new forms of victimization of relatives, communities and their companions.

\section{Self-care of people and intervening teams}

Standard 10: Provisions should be made for the comprehensive care, physical and psychological, of the people who carry out the technical, legal and psychosocial processes related to the search of victims of enforced disappearance, and extrajudicial or arbitrary executions.

\section{Cultural context}

Standard 11: Search processes for missing or executed persons, and forensic investigations, should be based on the culture and meanings of the population teams are working with.

\section{Gender approach}

Standard 12: The Psychosocial work should provide accompaniment to women to meet their particular needs during the process to seek truth, justice and comprehensive reparation.

\section{Work with children and adolescents}

Standard 13: The treatment given to children and adolescents who are victims, or somehow find themselves involved in cases of enforced disappearance, arbitrary execution or forensic investigations, should be different and special; taking into consideration the utmost interests of minors.

\section{Coordination}

Standard 14: Mechanisms to coordinate the actions of all actors involved- such as persons, families, communities, the State, international and non-governmental organizations-, should be guaranteed. This includes the process of gathering and analysing the information available, the legal, technical and psychosocial actions, as well as follow-up and assessment mechanisms for all actions to be undertaken.

\section{Independent teams}

Standard 15: To incorporate local, national and international organizations into the search processes and forensic investigations, whenever the situation requires it, in order to contribute to the effectiveness of the technical, legal and psychosocial processes, as well 
guaranteeing that the legal and scientific national and international standards are complied with, and the demand to act with transparency, independence and objectivity.

\section{Scientific standards in forensic work}

Standard 16: To guarantee that forensic work complies with national and international scientific and legal standards, ensuring that steps are taken to individualize and handle bodily remains in a proper manner, regardless of their having been identified or not. 


\section{Table 2: Matrix of possible actions to be implemented in psychosocial work in exhumation processes and the search} for disappeared or executed persons (Ecap, et al., 2009)

The activities proposed below represent a framework for action which should be adapted to the reality of each country or region.

\begin{tabular}{|c|c|c|c|c|}
\hline $\begin{array}{l}\text { Basic matrix of } \\
\text { work themes and } \\
\text { possible actions }\end{array}$ & $\begin{array}{l}\text { PREPARATORY WORK } \\
\text { BEFORE EXCAVATION } \\
\text { (previous months) }\end{array}$ & $\begin{array}{l}\text { WORK AROUND TIME OF EXCAVATION } \\
\text { (previous weeks, during excavation } \\
\text { and subsequent weeks) }\end{array}$ & $\begin{array}{l}\text { WORK DURING } \\
\text { WAITING PERIOD } \\
\text { AND INHUMATION }\end{array}$ & $\begin{array}{l}\text { INTEGRAL MEDIUM } \\
\text { AND LONG TERM } \\
\text { ACTIONS }\end{array}$ \\
\hline 1. COORDINATION & $\begin{array}{l}\text { - Determine national or } \\
\text { international institutions that } \\
\text { work in exhumations and } \\
\text { seek possibilities of } \\
\text { consensus and joint work. } \\
\text { - Identify networks of } \\
\text { institutions that can } \\
\text { potentially provide support in } \\
\text { exhumation processes. } \\
\text { - Develop national } \\
\text { exhumation policies in } \\
\text { consensus with all actors, } \\
\text { particularly victims' } \\
\text { associations, that respect the } \\
\text { principles and standards } \\
\text { agreed on in this guide. } \\
\text { - Incorporate the } \\
\text { exhumation policy into the } \\
\text { agenda of national human } \\
\text { rights agencies. } \\
\text { - Find stable mixed sources } \\
\text { of funding, preferably State } \\
\text { sources. }\end{array}$ & $\begin{array}{l}\text { - Set up coordination systems between } \\
\text { institutions: roles, responsibilities, } \\
\text { meetings and decision making } \\
\text { systems. } \\
\text { - Establish coordinated diagnosis and } \\
\text { evaluation systems (see section 2), } \\
\text { avoiding duplication of actions (e.g. } \\
\text { interviews). } \\
\text { - Encourage the participation of } \\
\text { relatives in decision making at key } \\
\text { times to adapt to the needs and } \\
\text { desires of relatives: } \\
\text { - excavation dates } \\
\text { - starting time } \\
\text { - presentation of clothing } \\
\text { - closing of graves } \\
\text { - symbolic rituals and ceremonies } \\
\text { - Coordination to facilitate logistical } \\
\text { support particularly for relatives with } \\
\text { fewer economic resources: } \\
\text { - transport from communities to the } \\
\text { exhumation } \\
\text { - support for lodging or meals if }\end{array}$ & $\begin{array}{l}\text { - Coordination of } \\
\text { activities during } \\
\text { waiting periods (visits } \\
\text { to laboratory and } \\
\text { other activities). } \\
\text { - Provision of } \\
\text { information on the } \\
\text { process in consensus. } \\
\text { - Inhumation } \\
\text { ceremony in } \\
\text { consensus with all the } \\
\text { institutions and in } \\
\text { accordance with the } \\
\text { religious or symbolic } \\
\text { requirements of } \\
\text { relatives. } \\
\text { - Contribute to the } \\
\text { process not being only } \\
\text { a private affair. }\end{array}$ & $\begin{array}{l}\text { - Develop a strategic } \\
\text { plan with the } \\
\text { organisations to: } \\
\text { - provide information } \\
\text { about the process } \\
\text { - provide information } \\
\text { about findings } \\
\text { - promote strategic } \\
\text { actions to achieve non- } \\
\text { repetition } \\
\text { - promote the inclusion } \\
\text { of lessons learned in } \\
\text { national policies on } \\
\text { exhumations. } \\
\text { - Encourage processes } \\
\text { to develop historical } \\
\text { memory (books, } \\
\text { ceremonies, } \\
\text { reminders...) } \\
\text { throughout the } \\
\text { country. }\end{array}$ \\
\hline
\end{tabular}




\begin{tabular}{|c|c|c|c|c|}
\hline $\begin{array}{l}\text { Basic matrix of } \\
\text { work themes and } \\
\text { possible actions }\end{array}$ & $\begin{array}{l}\text { PREPARATORY WORK } \\
\text { BEFORE EXCAVATION } \\
\text { (previous months) } \\
\end{array}$ & $\begin{array}{l}\text { WORK AROUND TIME OF EXCAVATION } \\
\text { (previous weeks, during excavation } \\
\text { and subsequent weeks) }\end{array}$ & $\begin{array}{l}\text { WORK DURING } \\
\text { WAITING PERIOD } \\
\text { AND INHUMATION }\end{array}$ & $\begin{array}{l}\text { INTEGRAL MEDIUM } \\
\text { AND LONG TERM } \\
\text { ACTIONS }\end{array}$ \\
\hline & $\begin{array}{l}\text { - Provide integral training for } \\
\text { each professional sector on } \\
\text { aspects of work related to } \\
\text { other sectors, in accordance } \\
\text { with the indications in this } \\
\text { guide. } \\
\text { - Promote training for legal } \\
\text { entities, police, etc. on } \\
\text { human rights and } \\
\text { exhumation processes in this } \\
\text { context. } \\
\text { - Coordination of all } \\
\text { institutions and organisations } \\
\text { to develop the work of } \\
\text { searching for and identifying } \\
\text { possible relatives, with } \\
\text { special emphasis on support } \\
\text { and resources for the } \\
\text { associations of individuals } \\
\text { affected. }\end{array}$ & $\begin{array}{l}\text { required } \\
\text { - support with child care or care for } \\
\text { others } \\
\quad \text { - support with digging, etc. }\end{array}$ & & \\
\hline $\begin{array}{l}\text { 2. PARTICIPATORY } \\
\text { DIAGNOSIS AND } \\
\text { EVALUATION }\end{array}$ & $\begin{array}{l}\text { - Understand the } \\
\text { expectations of relatives or } \\
\text { communities involved: } \\
\text { Why exhume the remains? } \\
\text { How do they imagine the } \\
\text { process? What conditions } \\
\text { should be present? } \\
\text { - Revise and systematise }\end{array}$ & $\begin{array}{l}\text { - Identification of entities and } \\
\text { organisations working in the region } \\
\text { and their services. } \\
\text { - Participatory diagnosis of: (a) reasons } \\
\text { for the exhumation (b) expectations } \\
\text { (c) perception of the social and political } \\
\text { climate (d) perception of justice (see } \\
\text { point (5), perception of reparation (see }\end{array}$ & $\begin{array}{l}\text { - Maintain monitoring } \\
\text { systems for } \\
\text { community impact. }\end{array}$ & $\begin{array}{l}\text { - Define opportunities } \\
\text { for periodical meetings } \\
\text { with victims to inform } \\
\text { them about progress, } \\
\text { concerns and prospects } \\
\text { of the process. } \\
\text { - Evaluation of the } \\
\text { impact of the }\end{array}$ \\
\hline
\end{tabular}




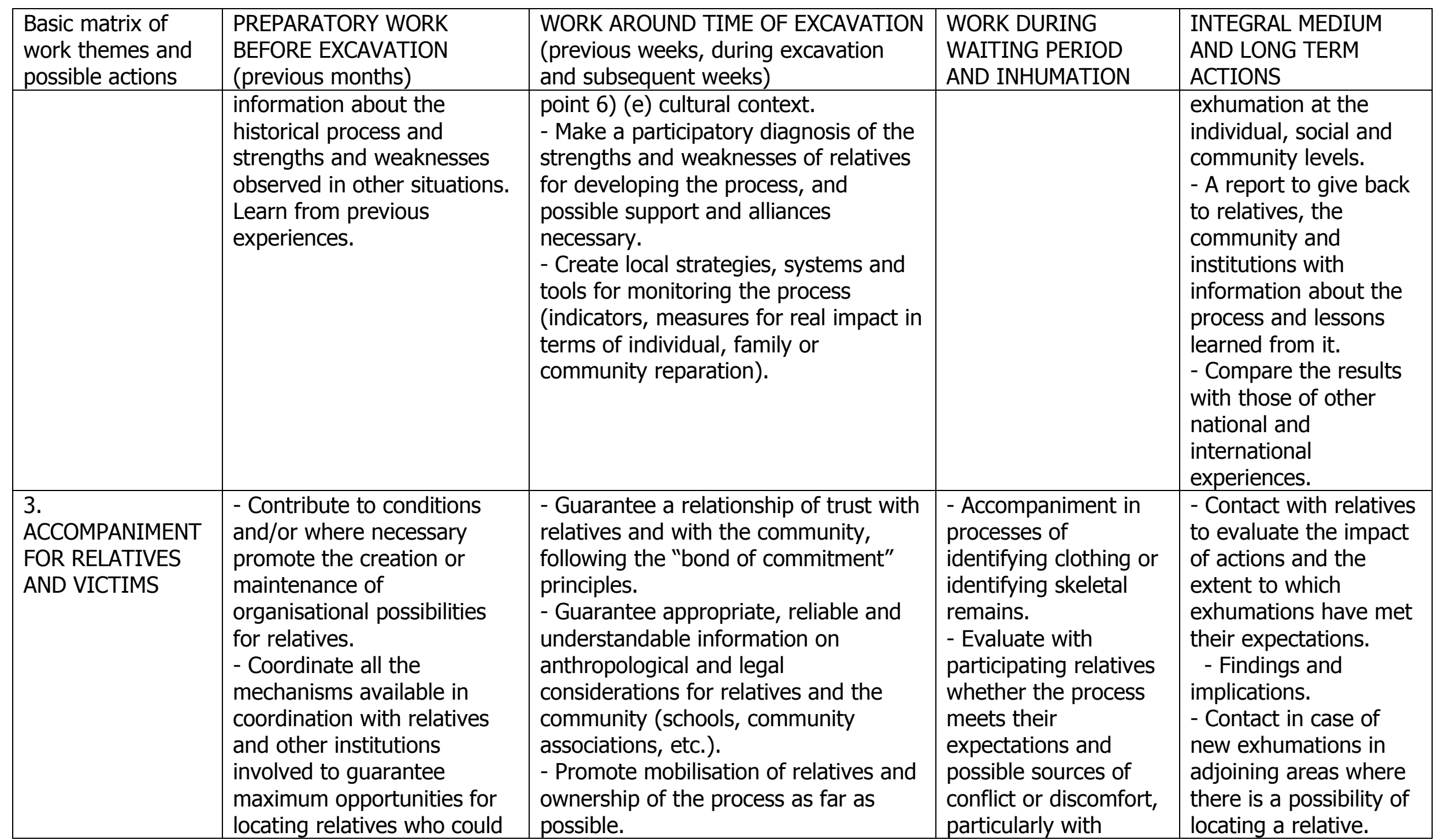




\begin{tabular}{|c|c|c|c|c|}
\hline $\begin{array}{l}\text { Basic matrix of } \\
\text { work themes and } \\
\text { possible actions }\end{array}$ & $\begin{array}{l}\text { PREPARATORY WORK } \\
\text { BEFORE EXCAVATION } \\
\text { (previous months) }\end{array}$ & $\begin{array}{l}\text { WORK AROUND TIME OF EXCAVATION } \\
\text { (previous weeks, during excavation } \\
\text { and subsequent weeks) }\end{array}$ & $\begin{array}{l}\text { WORK DURING } \\
\text { WAITING PERIOD } \\
\text { AND INHUMATION }\end{array}$ & $\begin{array}{l}\text { INTEGRAL MEDIUM } \\
\text { AND LONG TERM } \\
\text { ACTIONS }\end{array}$ \\
\hline & $\begin{array}{l}\text { potentially have relatives in } \\
\text { the exhumation process } \\
\text { (snowballing methodologies } \\
\text { and others). } \\
\text { - Creation of a registry of } \\
\text { relatives to permit fast } \\
\text { dissemination of information. }\end{array}$ & $\begin{array}{l}\text { - Understand the expectations and } \\
\text { motivations of relatives (see point 2). } \\
\text { Analyse and anticipate: } \\
\text { - the possibility of no findings } \\
\text { - the possibility of finding signs of } \\
\text { ill-treatment, cruelty or torture. } \\
\text { - Analyse the position of relatives in } \\
\text { relation to the whole community } \\
\text { (potential support and sources of } \\
\text { rejection; strategies; threats; rumours; } \\
\text { fear; conflict). } \\
\text { - Emotional support during the } \\
\text { excavation process and in view of } \\
\text { possible findings. } \\
\text { - Guarantee reliable and } \\
\text { understandable information from the } \\
\text { forensic anthropological and legal } \\
\text { processes. } \\
\text { - Support for the possible appearance } \\
\text { of organisational processes or of new } \\
\text { leaders. } \\
\text { - Encourage the emergence of self- } \\
\text { support groups. } \\
\text { - Encourage conditions for cultural and } \\
\text { religious practices to be adapted to the } \\
\text { demands of relatives. } \\
\text { - Support and accompaniment during } \\
\text { particularly significant symbolic times }\end{array}$ & $\begin{array}{l}\text { regard to emotional } \\
\text { and humanistic } \\
\text { considerations. } \\
\text { - Work with relatives } \\
\text { not found. } \\
\text { Perception of the task } \\
\text { as being completed or } \\
\text { not. } \\
\text { - Continuity of work: } \\
\text { - organisational } \\
\text { - local memory } \\
\text { - search for justice } \\
\text { (criminal or other). } \\
\text { - Information about } \\
\text { on-going forensic- } \\
\text { anthropological } \\
\text { aspects. } \\
\text { - Expectations and } \\
\text { organisation of } \\
\text { inhumation (individual } \\
\text { - collective; civil - } \\
\text { religious...). } \\
\text { - Give support and } \\
\text { follow-up to self- }\end{array}$ & $\begin{array}{l}\text { - Involve the more } \\
\text { motivated relatives in } \\
\text { compiling a historical } \\
\text { memory (testimonies, } \\
\text { books, ceremonies, } \\
\text { remembering...) } \\
\text { throughout the } \\
\text { country. } \\
\text { - Coordination with } \\
\text { public health } \\
\text { institutions or human } \\
\text { rights agencies to } \\
\text { provide care for } \\
\text { relatives with serious } \\
\text { traumas. }\end{array}$ \\
\hline
\end{tabular}




\begin{tabular}{|c|c|c|c|c|}
\hline $\begin{array}{l}\text { Basic matrix of } \\
\text { work themes and } \\
\text { possible actions }\end{array}$ & $\begin{array}{l}\text { PREPARATORY WORK } \\
\text { BEFORE EXCAVATION } \\
\text { (previous months) }\end{array}$ & $\begin{array}{l}\text { WORK AROUND TIME OF EXCAVATION } \\
\text { (previous weeks, during excavation } \\
\text { and subsequent weeks) }\end{array}$ & $\begin{array}{l}\text { WORK DURING } \\
\text { WAITING PERIOD } \\
\text { AND INHUMATION } \\
\end{array}$ & $\begin{array}{l}\text { INTEGRAL MEDIUM } \\
\text { AND LONG TERM } \\
\text { ACTIONS } \\
\end{array}$ \\
\hline & & $\begin{array}{l}\text { which are religious or social or related } \\
\text { to the community. } \\
\text { - Joint work with culturally recognised } \\
\text { figures to provide attention and } \\
\text { support for analysing dreams, } \\
\text { nightmares, apparitions, ceremonies.... }\end{array}$ & $\begin{array}{l}\text { support groups. } \\
\text { - Continuation of the } \\
\text { collective testimony. } \\
\text { - Exchange with other } \\
\text { working groups to } \\
\text { share experiences and } \\
\text { for mutual support so } \\
\text { that experiences not } \\
\text { be restricted to small } \\
\text { groups. }\end{array}$ & \\
\hline $\begin{array}{l}\text { 4. COMMUNITY } \\
\text { PROCESS } \\
\text { 4.1. Historical } \\
\text { Memory / Truth } \\
\text { 4.2. Support for } \\
\text { victims and } \\
\text { relatives } \\
\text { 4.3. Attention for } \\
\text { special groups: } \\
\text { children, former } \\
\text { perpetrators... }\end{array}$ & $\begin{array}{l}\text { - Preparation (preferably } \\
\text { with IAP techniques) of a } \\
\text { map of networks of } \\
\text { community authorities and } \\
\text { institutions and their position } \\
\text { in support or rejection of } \\
\text { exhumation. } \\
\text { - Analysis and } \\
\text { documentation of the } \\
\text { historical process and violent } \\
\text { events. Actors and current } \\
\text { status of conflict. } \\
\text { - View of relatives in the } \\
\text { community (support, } \\
\text { stigmatisation...). Mapping } \\
\text { of risks and potential } \\
\text { coverage and management } \\
\text { strategies. }\end{array}$ & $\begin{array}{l}\text { - Promote community actions to } \\
\text { provide psychosocial support for } \\
\text { relatives and victims. } \\
\text { - Learn and/or coordinate with } \\
\text { culturally significant figures (traditional } \\
\text { authorities, healers, spiritual or social } \\
\text { leaders). } \\
\text { - Involve different sectors (schools, } \\
\text { churches, local or regional media). } \\
\text { - Promote the participation of } \\
\text { volunteers in the community in tasks } \\
\text { related to exhumation, as a form of } \\
\text { support and dignity for relatives } \\
\text { (digging, assistance with shelter or } \\
\text { food, cultural ceremonies or } \\
\text { dissemination). } \\
\text { - Promote local actions to recover the } \\
\text { historical memory. }\end{array}$ & $\begin{array}{l}\text { - Evaluation of the } \\
\text { impact on the } \\
\text { community of the } \\
\text { exhumation in terms } \\
\text { of community } \\
\text { cohesion versus } \\
\text { polarisation / conflict; } \\
\text { opening of new } \\
\text { organisational } \\
\text { opportunities or } \\
\text { others. }\end{array}$ & $\begin{array}{l}\text { - Development of a } \\
\text { sense of ownership of } \\
\text { the process among } \\
\text { community members. } \\
\text { - Understanding the } \\
\text { exhumation as an } \\
\text { integral development } \\
\text { process for the } \\
\text { community. } \\
\text { - Take steps to permit } \\
\text { sectors of the } \\
\text { community to "put a } \\
\text { human face" on their } \\
\text { recent history to } \\
\text { understand the } \\
\text { significance and scope } \\
\text { of exhumations as well }\end{array}$ \\
\hline
\end{tabular}




\begin{tabular}{|c|c|c|c|c|}
\hline $\begin{array}{l}\text { Basic matrix of } \\
\text { work themes and } \\
\text { possible actions } \\
\end{array}$ & $\begin{array}{l}\text { PREPARATORY WORK } \\
\text { BEFORE EXCAVATION } \\
\text { (previous months) }\end{array}$ & $\begin{array}{l}\text { WORK AROUND TIME OF EXCAVATION } \\
\text { (previous weeks, during excavation } \\
\text { and subsequent weeks) }\end{array}$ & $\begin{array}{l}\text { WORK DURING } \\
\text { WAITING PERIOD } \\
\text { AND INHUMATION } \\
\end{array}$ & $\begin{array}{l}\text { INTEGRAL MEDIUM } \\
\text { AND LONG TERM } \\
\text { ACTIONS } \\
\end{array}$ \\
\hline & $\begin{array}{l}\text { - Existence of groups } \\
\text { particularly sensitive to the } \\
\text { process (presence of } \\
\text { perpetrators in the } \\
\text { community...). } \\
\text { - Detection of actors or } \\
\text { community institutions with } \\
\text { whom it would be possible to } \\
\text { carry out coordination or } \\
\text { awareness raising (schools, } \\
\text { youth centres, historical or } \\
\text { cultural associations, } \\
\text { universities...). }\end{array}$ & $\begin{array}{l}\text { - Identify the relation between the } \\
\text { local context and possible conflicts in } \\
\text { the national political context. } \\
\text { - Analyse the presence of perpetrators } \\
\text { in the community. Possible conflicts. }\end{array}$ & & $\begin{array}{l}\text { as the experience of } \\
\text { relatives. }\end{array}$ \\
\hline $\begin{array}{l}\text { 5. LEGAL ASPECTS } \\
\text { 5.1. Legal } \\
\text { process } \\
5.2 \text { Criminal } \\
\text { proceedings }\end{array}$ & $\begin{array}{l}\text { 5.1. Legal process. } \\
\text { - Coordinate accompaniment } \\
\text { for legal formalities to start } \\
\text { the process (complaint, } \\
\text { ratification, testimony or } \\
\text { others). } \\
\text { - Accompaniment for a prior } \\
\text { visit to the possible place of } \\
\text { the exhumation. } \\
\text { 5.2. Criminal proceedings. } \\
\text { Discuss the right of relatives }\end{array}$ & $\begin{array}{l}\text { 5.1. Legal Process. } \\
\text { - Coordinate accompaniment for legal } \\
\text { formalities with possible organisational } \\
\text { or emotional implications. } \\
\text { - Support for the legal team to achieve } \\
\text { an appropriate and reliable } \\
\text { understanding of technical legal } \\
\text { aspects by relatives or the community. } \\
\text { - In all processes guarantee } \\
\text { appropriate respect for the human } \\
\text { rights of relatives and victims } \\
\text { (confidentiality, privacy, security...). } \\
\text { - Guarantee adequate witness } \\
\text { protection in places where massacres } \\
\text { or war crimes occurred. }\end{array}$ & $\begin{array}{l}\text { 5.1. Legal process. } \\
\text { - Explain and analyse } \\
\text { the implications and } \\
\text { consequences of } \\
\text { identification. } \\
\text { 5.2. Criminal } \\
\text { proceedings. } \\
\text { - Support the } \\
\text { discussion and/or } \\
\text { measures if any } \\
\text { relatives decide to } \\
\text { take this path. } \\
\text { - Coordinate } \\
\text { proceedings against }\end{array}$ & $\begin{array}{l}\text { - Promote the } \\
\text { ratification of } \\
\text { international } \\
\text { conventions on the } \\
\text { prevention of torture or } \\
\text { international criminal } \\
\text { jurisdiction in the } \\
\text { country. } \\
\text { - Promote legal reforms } \\
\text { to prevent impunity for } \\
\text { acts of genocide or } \\
\text { crimes against } \\
\text { humanity. }\end{array}$ \\
\hline
\end{tabular}




\begin{tabular}{|c|c|c|c|c|}
\hline $\begin{array}{l}\text { Basic matrix of } \\
\text { work themes and } \\
\text { possible actions }\end{array}$ & $\begin{array}{l}\text { PREPARATORY WORK } \\
\text { BEFORE EXCAVATION } \\
\text { (previous months) }\end{array}$ & $\begin{array}{l}\text { WORK AROUND TIME OF EXCAVATION } \\
\text { (previous weeks, during excavation } \\
\text { and subsequent weeks) }\end{array}$ & $\begin{array}{l}\text { WORK DURING } \\
\text { WAITING PERIOD } \\
\text { AND INHUMATION }\end{array}$ & $\begin{array}{l}\text { INTEGRAL MEDIUM } \\
\text { AND LONG TERM } \\
\text { ACTIONS }\end{array}$ \\
\hline & $\begin{array}{l}\text { to have access to justice and } \\
\text { possible coordination of } \\
\text { actions with all institutions } \\
\text { involved. }\end{array}$ & $\begin{array}{l}\text { 5.2. Criminal proceedings. Create } \\
\text { opportunities for discussion of the } \\
\text { possibility of relatives or the } \\
\text { community initiating a lawsuit against } \\
\text { perpetrators. }\end{array}$ & $\begin{array}{l}\text { perpetrators with } \\
\text { relatives from other } \\
\text { exhumations in the } \\
\text { case of regional } \\
\text { violence. } \\
\text { - Design a psycho- } \\
\text { legal strategy. }\end{array}$ & \\
\hline $\begin{array}{l}\text { 6. FORENSIC } \\
\text { ANTHROPOLOGIC } \\
\text { AL ASPECTS }\end{array}$ & $\begin{array}{l}\text { - Make visual } \\
\text { interdisciplinary inspections } \\
\text { to establish communication } \\
\text { and encourage initial } \\
\text { contacts with relatives. }\end{array}$ & $\begin{array}{l}\text { - Support for the anthropological team } \\
\text { to achieve an adequate and reliable } \\
\text { understanding by relatives or the } \\
\text { community of technical forensic- } \\
\text { anthropological aspects } \\
\text { - ante mortem records } \\
\text { - value of different evidence for } \\
\text { identification (clothing, physical signs, } \\
\text { DNA...) } \\
\text { - custody and storage of remains } \\
\text { - Presence during the preparation of } \\
\text { ante mortem records. }\end{array}$ & $\begin{array}{l}\text { - Accompany the } \\
\text { process of identifying } \\
\text { clothing or remains, } \\
\text { seeking opportunities } \\
\text { for emotional and } \\
\text { community } \\
\text { strengthening. } \\
\text { - Psychosocial aspects } \\
\text { related to } \\
\text { looking after the } \\
\text { remains and the } \\
\text { laboratory procedure. } \\
\text { Communication to } \\
\text { relatives and the } \\
\text { possibility of guided } \\
\text { visits by groups of } \\
\text { relatives to the } \\
\text { laboratory. }\end{array}$ & \\
\hline
\end{tabular}




\begin{tabular}{|c|c|c|c|c|}
\hline $\begin{array}{l}\text { Basic matrix of } \\
\text { work themes and } \\
\text { possible actions }\end{array}$ & $\begin{array}{l}\text { PREPARATORY WORK } \\
\text { BEFORE EXCAVATION } \\
\text { (previous months) }\end{array}$ & $\begin{array}{l}\text { WORK AROUND TIME OF EXCAVATION } \\
\text { (previous weeks, during excavation } \\
\text { and subsequent weeks) }\end{array}$ & $\begin{array}{l}\text { WORK DURING } \\
\text { WAITING PERIOD } \\
\text { AND INHUMATION }\end{array}$ & $\begin{array}{l}\text { INTEGRAL MEDIUM } \\
\text { AND LONG TERM } \\
\text { ACTIONS }\end{array}$ \\
\hline $\begin{array}{l}\text { 7. COMPENSATION } \\
\text { AND REPARATION } \\
7.1 \text {. Relation } \\
\text { with authorities } \\
7.2 \text {. } \\
\text { Compensation and } \\
\text { reparation } \\
\text { programmes }\end{array}$ & $\begin{array}{l}\text { - Encourage an analysis of } \\
\text { the right to integral } \\
\text { reparation, this being } \\
\text { understood not only as a } \\
\text { possibility to relieve the } \\
\text { effects of damages caused } \\
\text { by the crimes, but also as a } \\
\text { form of generating } \\
\text { transformation of the } \\
\text { conditions that led to } \\
\text { violations, thus avoiding } \\
\text { their repetition. } \\
\text { - Work in a participatory way } \\
\text { in relation to victims' } \\
\text { expectations of reparation. } \\
\text { - Enable communication of } \\
\text { victims with state entities } \\
\text { responsible for reparation } \\
\text { policies. }\end{array}$ & $\begin{array}{l}\text { - Make the analysis and actions } \\
\text { possible in relation to locating the } \\
\text { whereabouts of disappeared persons, } \\
\text { as a form of reparation. } \\
\text { - Pay attention to all aspects related to } \\
\text { respect for remains, dignified } \\
\text { treatment of the deceased and of } \\
\text { relatives. }\end{array}$ & $\begin{array}{l}\text { - Involvement of state } \\
\text { entities responsible for } \\
\text { reparation policies in } \\
\text { relation to actions by } \\
\text { victims in exhumation } \\
\text { processes. }\end{array}$ & $\begin{array}{l}\text { - Memorials and } \\
\text { monuments and other } \\
\text { forms of symbolic } \\
\text { reparation. } \\
\text { - Define the actions } \\
\text { necessary for adequate } \\
\text { social, economic, } \\
\text { educational or medical } \\
\text { support for the } \\
\text { survivors of massacres } \\
\text { or relatives of victims. } \\
\text { - Improve relations } \\
\text { with state entities } \\
\text { responsible for } \\
\text { reparation policies. } \\
\text { - Improve relations of } \\
\text { victims with reparation } \\
\text { programs so they can } \\
\text { demand their right to } \\
\text { integral reparation. }\end{array}$ \\
\hline 8. INFORMATION & $\begin{array}{l}\text { - Make a map of the local } \\
\text { and regional media and } \\
\text { possible position in the } \\
\text { process. } \\
\text { - Existence and handling of } \\
\text { rumours and other sources } \\
\text { of division. }\end{array}$ & $\begin{array}{l}\text { - Analyse the level of visibility that } \\
\text { relatives and organisations involved } \\
\text { wish the exhumation to have. } \\
\text { - Guarantee reliable, respectful } \\
\text { information in the appropriate political } \\
\text { context for the local, national and } \\
\text { international media. } \\
\text { - Prevent unethical use of images. }\end{array}$ & & $\begin{array}{l}\text { - Improve or develop } \\
\text { community structures } \\
\text { which contribute to } \\
\text { disseminating the } \\
\text { collective memory of } \\
\text { events and the process } \\
\text { being carried out by } \\
\text { relatives or }\end{array}$ \\
\hline
\end{tabular}




\begin{tabular}{|c|c|c|c|c|}
\hline $\begin{array}{l}\text { Basic matrix of } \\
\text { work themes and } \\
\text { possible actions } \\
\end{array}$ & $\begin{array}{l}\text { PREPARATORY WORK } \\
\text { BEFORE EXCAVATION } \\
\text { (previous months) }\end{array}$ & $\begin{array}{l}\text { WORK AROUND TIME OF EXCAVATION } \\
\text { (previous weeks, during excavation } \\
\text { and subsequent weeks) }\end{array}$ & $\begin{array}{l}\text { WORK DURING } \\
\text { WAITING PERIOD } \\
\text { AND INHUMATION } \\
\end{array}$ & $\begin{array}{l}\text { INTEGRAL MEDIUM } \\
\text { AND LONG TERM } \\
\text { ACTIONS } \\
\end{array}$ \\
\hline & & & & organisations. \\
\hline 9. WORK TEAMS & $\begin{array}{l}\text { - Develop training processes } \\
\text { to accompany exhumations. } \\
\text { - Promote the establishment } \\
\text { of multicultural teams. } \\
\text { - Promote teams with gender } \\
\text { perspective. }\end{array}$ & $\begin{array}{l}\text { - Steps to give attention to the teams. } \\
\text { - Promote ethical and responsible } \\
\text { behaviour in the teams (use of tape } \\
\text { recorders or cameras, respect for local } \\
\text { customs in clothing, attitude, etc.). }\end{array}$ & & \\
\hline
\end{tabular}


Table 3. Exhumations analyzed in this study (Pérez-Sales and García2007b) (Navarro-García, et al., 2010).

\begin{tabular}{|c|c|c|c|c|c|}
\hline & \multirow[b]{2}{*}{$\begin{array}{l}\text { Instigated } \\
\text { by: }\end{array}$} & \multirow{2}{*}{$\begin{array}{c}\text { Forensic Anthropology } \\
\text { Investigation/Vision of the } \\
\text { Relatives } \\
\text { EG: Governmental teams } \\
\text { EIL: Independent local } \\
\text { teams } \\
\text { EII: Independent } \\
\text { international teams }\end{array}$} & \multicolumn{2}{|c|}{ Legal Proceedings } & \multirow[b]{2}{*}{$\begin{array}{l}\text { Psychosocial } \\
\text { Accompaniment }\end{array}$} \\
\hline & & & $\begin{array}{l}\text { Pre-trial } \\
\text { proceedings } \\
\text { promoted by: }\end{array}$ & $\begin{array}{c}\text { Subsequent access } \\
\text { to justice } \\
\text { (convictions of } \\
\text { perpetrators) }\end{array}$ & \\
\hline \multicolumn{6}{|c|}{ Exhumations and collective massacres } \\
\hline $\begin{array}{l}\text { El } \\
\text { Salvador }\end{array}$ & $\begin{array}{l}\text { Relatives } \\
\text { Organizations } \\
\text { Human Rights }\end{array}$ & EII (EAAF) - Adequate & NGOs & $\begin{array}{l}\text { No, despite long legal } \\
\text { battle }\end{array}$ & $\begin{array}{l}\text { Self-support } \\
\text { Relatives }\end{array}$ \\
\hline \multirow[t]{2}{*}{ Colombia } & Relatives & EIL - Adequate & NGOs & No & NGOs (irregular) \\
\hline & $\begin{array}{l}\text { States } \\
\text { (majority) }\end{array}$ & $\begin{array}{l}\text { EG - Inadequate (Destruction } \\
\text { of evidence; no identification of } \\
\text { remains (double } \\
\text { disappearance); retraumatizing } \\
\text { actions for relatives) }\end{array}$ & $\begin{array}{l}\text { Office of Public } \\
\text { Prosecution } \\
\text { (Official) }\end{array}$ & No & No \\
\hline Guatemala & Relatives & EIL - Adequate & $\begin{array}{l}\text { Relatives } \\
\text { NGOs }\end{array}$ & $\begin{array}{l}\text { No ( } 99.5 \% \text { of cases) } \\
\text { Yes ( } 0.5 \% \text { of cases in } \\
\text { international courts } \\
\text { (Inter-American Court } \\
\text { of Human Rights)) }\end{array}$ & $\begin{array}{l}\text { Yes (systematic } \\
\text { and formally } \\
\text { registered) }\end{array}$ \\
\hline \multirow[t]{2}{*}{ Peru } & $\begin{array}{l}\text { Relatives } \\
\text { Organizations } \\
\text { Human Rights } \\
\text { Truth } \\
\text { Commission }\end{array}$ & \multirow[t]{2}{*}{$\begin{array}{l}\text { EG - Inadequate (no } \\
\text { identification of remains, } \\
\text { destruction of evidence in } \\
\text { some cases (Frontón) }\end{array}$} & NGOs & No & NGOs (irregular) \\
\hline & State & & $\begin{array}{l}\text { Office of Public } \\
\text { Prosecution } \\
\text { (Official) }\end{array}$ & No & No \\
\hline \multicolumn{6}{|c|}{ Detainees-disappeared persons as state policy } \\
\hline Chile & $\begin{array}{l}\text { Courts } \\
\text { (current) }\end{array}$ & $\begin{array}{l}\text { EG - Irregular (Patio } 29 \text { Case } \\
\text { and identification errors) }\end{array}$ & $\begin{array}{l}\text { Office of Public } \\
\text { Prosecution } \\
\text { (Official) }\end{array}$ & Some cases & $\begin{array}{l}\text { Ministry of the } \\
\text { Interior } \\
\text { NGOs }\end{array}$ \\
\hline Argentina & $\begin{array}{l}\text { Courts }^{1} \\
\text { (current) }\end{array}$ & EIL - Adequate & $\begin{array}{l}\text { Office of Public } \\
\text { Prosecution } \\
\text { (Official) }\end{array}$ & No & No \\
\hline
\end{tabular}

\footnotetext{
${ }^{2}$ Relatives / NGOs (before 1990)
} 


\begin{tabular}{|c|c|c|c|c|c|}
\hline Uruguay & Relatives & EIL - Adequate & NGOs & No & No \\
\hline Brazil & Relatives & $\begin{array}{l}\text { EII / EIL - Inadequate } \\
\text { (absence of clear information; } \\
\text { work interrupted, not agreed } \\
\text { on ...) }\end{array}$ & NGOs & No & No \\
\hline Paraguay & $\begin{array}{l}\text { Truth } \\
\text { Commission }\end{array}$ & EII - EAAF & $\begin{array}{l}\text { Truth } \\
\text { Commission }\end{array}$ & No & Truth Commission \\
\hline \multicolumn{6}{|c|}{ Exhumations and social violence } \\
\hline Venezuela & Relatives & $\begin{array}{l}\text { EG - Inadequate (destruction } \\
\text { of evidence; reburial too soon } \\
\text { and without consulting; no } \\
\text { identification of remains) }\end{array}$ & Relatives & $\begin{array}{l}\text { No (Venezuelan legal } \\
\text { system did not impose } \\
\text { sentences; favourable } \\
\text { sentence obtained only } \\
\text { in Inter-American } \\
\text { Court of Human Rights) }\end{array}$ & Self-support \\
\hline Mexico & Relatives & $\begin{array}{l}\text { EG - Inadequate (destruction } \\
\text { of evidence; erroneous } \\
\text { identifications; retraumatizing } \\
\text { actions for relatives) } \\
\text { EII (EAAF) - Adequate }\end{array}$ & $\begin{array}{l}\text { Relatives } \\
\text { NGOs }\end{array}$ & No & NGOs (Irregular) \\
\hline Panama & Relatives & $\begin{array}{l}\text { EG - Inadequate (use of heavy } \\
\text { machinery; identification } \\
\text { errors) }\end{array}$ & $\begin{array}{l}\text { Office of Public } \\
\text { Prosecution } \\
\text { (Official) }\end{array}$ & No & No \\
\hline \multicolumn{6}{|c|}{ Selective deaths under democratic regimes } \\
\hline Ecuador & Relatives & EG - Inadequate (delay tactics) & Relatives & No & No \\
\hline Honduras & Relatives & EII - Adequate & Relatives & No & $\begin{array}{l}\text { Self-support } \\
\text { Relatives }\end{array}$ \\
\hline
\end{tabular}

EAAF, Argentine Forensic Anthropology Team; NGO, non-governmental organization 